\title{
Mass Media - Human Being - Society: Specifics of Interaction in the Digital Age
}

\author{
Denis I. Chistyakov ${ }^{1, *}$ \\ ${ }^{1}$ Hotel Business and Tourism Institute, Peoples' Friendship University of Russia (RUDN University), 6 \\ Miklukho-Maklaya Street, Moscow 117198, Russian Federation \\ *Corresponding author.Email: chistyakov-di@rudn.ru
}

\begin{abstract}
The article analyzes the problems of interaction between modern media, the individual, and social groups. It shows the change in the impact of the media on the target audience in the movement of society from modern to postmodern and traditional media to digital. The article reviews the relevant sociological and philosophical concepts that comprehend the changing relationship between society and mass-media communicators $-\mathrm{S}$. Zizek, A. Giddens, H. Blumer, D. McQuail, J. Baudrillard, R. Debray, S. Kravchenko, and others. Modern mass media is presented in the article as a specific social institution, which has all the means and possibilities to exert a powerful influence on society and the individual. Particular attention is paid to the processes of institutionalization of the mass media, which allows the latter to imitate the natural interactions of social groups and communicators, and thus imitate the method of communication itself. It is emphasized that in this way, the mass media expand their potential to regulate the social and political life of any country.
\end{abstract}

Keywords: Media and individual, Mediatization of society, Print media, Digital media, Information, The social institution of media.

\section{INTRODUCTION}

Considering the problems of media impact on an individual and society, we must proceed from the most crucial theoretical premise that the person of the modern world (whether he or she is a receiver, passively perceiving information, or a communicator, creating certain media content) is included in communication relations of a radically different nature than in the previous period, defined by sociologists as late modernity or heavy modernity ( $\mathrm{Z}$. Bauman), radical modernity or runaway world (A. Giddens).

Russian scholar S.A. Kravchenko notes that a "reflexive meta-paradigm" [1] of analytical discourse emerged from analyzing the essential characteristics and social realities of the "late" stage of modernity's development. Within the framework of this paradigm, academic theories show the process of forming a qualitatively new society. This process is characterized by profound institutional

*Fund: The reported study was funded by RFBR and MOST according to the research project N 20-511-S52002 "Philosophy of Being Human as the Core of Interdisciplinary Research". changes, accelerating structural and functional movement of society towards a greater degree of self-organization, individualism, risk, abolition of old forms of social organization, and their transition into radically new ones. Contemporary sociologist $\mathrm{U}$. Beck defined this stage of modernity as reflexive modernity, which depends on itself, and in which modernization melts all the usual communicative and institutional ties [2].

Modern civilizational societies are covered by postmodern processes in all spheres of social life, in the mass media segment and the qualitatively new information and communication space created by them. By the beginning of the $21^{\text {st }}$ century, mass communications have undergone radical changes and are associated with the globalization, informatization, and technocratization of society. New media forms have appeared (Internet, mobile technologies, alternative information, and social networks), which constitute and determine social life and the individual's life in the digital age.

In this era, social interactions are primarily determined and conditioned by specific 
communications, cultural and informational influence, the process of mediatization [3], which is a consequence of the development of mass media and their acquisition of dominant power in the postmodern society.

This article traces the characteristics and problems of the relationship between digital media and the groups of people on whom their influence is directed.

\section{MAN AND SOCIETY IN THE SPACE OF TRADITIONAL AND DIGITAL COMMUNICATIONS}

Postmodern individuals, immersed in screen culture, find themselves under the influence of technologically advanced communications and become a product of a phenomenon called new media. Slovenian philosopher S. Zizek calls the process of involvement of a real subject, society as a whole, in the artificial world of media signs, connotations, messages progressive mediatization. Total penetration of media messages into people's real lives affects everyday life in such a way that "the subject finds itself more and more 'mediated,' 'mediatized,' imperceptibly deprived of its power under the false cover of its alleged enhancement..." [4]. S. Zizek writes in his work about how modern culture is taking over society, changing consciousness, turning a person and the world around him into a virtual, artificial one. Mediatization, from his point of view, turns everything real into artificial [4]. Without succumbing to the absolutization of the trends described by S. Zizek, we should note that he captures the very essence of contemporary sociocultural processes associated with the influence of mass media structures on society and each individual. In the postmodern era, the subject is involved in endlessly circulating information streams, for the production and transmission of which the means of mass communication, or mass media, were created.

The first traditional mass media structures (newspapers, magazines, cinema, radio) emerged in the 1920s and 1930s, and their products were formed for broad, mass consumption. Let us emphasize that the both terms mass media and mass communications appeared in the early $20^{\text {th }}$ century, based on the need to explain the new society of the late modern era, emerging based on industrialization, ideas of democracy, and mass migrations. American mass communication theorist Denis McQuail believes that mass media already in the early period of its existence gradually gained critical importance and claimed to justify an entirely new type of society associated with the rapid formation of nation-states, industrial development, accelerated urbanization, recent political and religious ideas, and migration processes [5].

Since the emergence of the first media theoretical directions in the substantiation of mass communications, conceptual approaches to understanding the activities of the media and their impact on individual and public consciousness are formed. The first wave of general discussions about the place and role of mass media in society, and the first outbursts of social unrest caused by understanding the importance of the media as a new social phenomenon also emerge.

Beginning with the early, traditional massmedia structures and as they emerged and evolved into a powerful social institution of our time, sociologists proceeded primarily from analyzing the audience for whom the media were created. Analytical descriptions of the target audience of the first media were quite close to a substantive understanding of the mass or mass community of people. The original meaning (still largely retained today) of the mass communication category derives from an account of the association of people into a certain mass, and to a greater extent from an understanding of the characteristics of the mass media than from the idea of communication. In general, the media audience has been characterized as a mass aggregation of people who cannot be counted, with an undifferentiated homogeneous composition and a lack of internal structure, pragmatic order, and rational targeting. Such an audience, as a rule, is characterized by a psychologically negative perception of events or proposals coming from the power structures.

The concept of mass society was widely scientifically developed in the 1940s-1950s. The American sociologist Herbert Blumer was one of the first to formulate a definition of a mass audience, viewing it as a new type of social formation in modern society, which is the opposite of the group, the crowd, and the public [6]. The mass audience, in his opinion, is characterized by a large number of readers, viewers, listeners, that is, those persons who receive transmitted messages in various forms, and hence its high level of dispersion. According to Blumer, there is a noninteractive and anonymous character, homogeneity, disorganization, and the actions of people are often 
independent and unsystematic within the mass media audience. Due to its susceptibility to such principles, the mass audience becomes an object of manipulation by media structures in the early stages of its genesis.

In the following decades, the understanding of masses became the focus of many theoretical and sociological trends and empirical research in the humanities. During this period, the categorical structure of the social sciences was replenished mainly by the harmful content of terms related to mass society. Sociologist L. Bramson noted that the early understanding of the masses derived from the meaning of ordinary people, uneducated, irrational, unmanageable, potentially violent, ready to move to the side of the protesting crowd at the critical moment of social clashes [7]. This kind of mass social movement had to be controlled and guided. The mass media of the first half of the 20th century form a communication model, providing the necessary control and appropriate content of the information messages transmitted.

In his theory, D. McQuail states the following typological features of the already determined model of communications between the producers of information and society, arising from the objective characteristics of the development of mass media:

- 1. Centralized content production by several large channels with a centralperipheral large-scale distribution system, as a rule, hierarchical and unidirectional.

- 2. The organization of production and distribution takes place according either to the market's logic or as a state institution of public communication.

- 3. The content of messages in standardized forms is open to all but is also subject to normative censorship and political oversight.

- 4. The mass audience of information recipients consists of scattered, separate, isolated, anonymous individuals.

- 5. The realization of the primary goal of convincing and informing people in communications depends on the prestige and popularity of media sources, the implementation of monopolistic control of channels, the skill, and professionalism of practitioners who create messages [5].

McQuail's communication model has a recognized place in contemporary society, even in a more structured and stratified form than in the early stage of its emergence.

\section{THE SPECIFICS OF THE RELATIONSHIP BETWEEN MASS MEDIA AND SOCIETY IN THE POSTMODERN WORLD}

Let us note that the leading and most significant descriptive characteristic of mass communication is its simultaneous targeting of many recipients (oneto-many). The audience, invisible to the communicator but assumed to be a particular target audience in the postmodern era, becomes an object for directed information influence by media structures. Thanks mainly to digital technologies, communication in the mass media/society relationship is a unilateral, unidirectional, and impersonal process: only the mass media themselves participate in it, with no corresponding response from individuals or groups of people.

In this connection, the information and communication space of postmodern society is formed in such a way that the "communicatorrecipient" relationship is not only asymmetrical but is often in line with subordination, dependence, and manipulative influence. J. Baudrillard wrote on this subject in For a Critique of the Political Economy of the Sign that the impact of the media is as unidirectional as the realization of power through one-way communication. A media text can never be answered. Therefore, according to Baudrillard, the mass communication media carry out noncommunication, functioning as agents of power [8].

Today's world's content of communication messages is mass-produced, uninterrupted, standardized, turning into a constantly circulating stream. The constant reproduction and repeated use of created media forms lead to a loss of objectivity and often eliminate the information presented's authenticity and realism. Such processes are especially relevant in the postmodern society, which is characterized, as J. Baudrillard aptly put it, by the constant "reproduction of reproduction" of images and signs and the mass production of "copies of copies" [9]. Once created and constantly reproduced by the world of mass media, the communicative space determines the creation of information content directed at the consumer, which never fades away [10].

The ideas of the French sociologist Régis Debray, the founder of mediology as a doctrine of the means of transmitting knowledge and traditions, are essential in considering the process of mass communication. The views of this thinker establish a new methodological approach to the 
consideration of the interaction between the media and the subjects who perceive their products.

The French thinker considers the term "communication" in a comparative analysis with the term "transmission," seeing in them the formation of two opposing categories and two processes, profoundly different and, at the same time, interdependent. Comparing communication and transmission, R. Debray respectively considers the former as a sociological category, meaning the circulation of messages at a specific moment in time and interindividual psychology between the sender and receiver of information. At the same time, comprehension of the latter is connected with the historical and anthropological understanding of the dynamics of collective memory, cultural traditions, and values. It has a starting point in some technical means and material carriers [11].

Most important in distinguishing the processes of communication and transmission is the fact of the presence or absence of a particular social institution that contributes to the dynamics of the messages transmitted. The author of mediology argues that for transmission, it is necessary to create institutions (Church, Party, Family, Company, School), and for "communication," it is crucial to establish means (mass-media). Those belong to a new generation of social institutions and aim at a mass target audience [11].

The French sociologist is critical of modern theorists' position that it is possible to transmit cultural values and knowledge through technical means of communication, much less through exhausted and historical media. The new mass media that have emerged in the postmodern society have overcome, disqualified the previous media, and redistributed the relationship between information providers and recipients. According to R. Debray, to conquer time by cultural transmission, one needs a "material machine" (for example, alphabetic writing) and necessarily a social institution.

The significant fact plays a vital role in the movement of these two processes (transmission and communication) that the mass-media industry "outpaces the institutions that enjoy a slow pace of transmission" [11]. The holistic system of mass media is ahead of the social institutions that perform the transmission of knowledge, culture, and collective memory from one generation to the next.
Indeed, social institutions today, in our opinion, lag behind the new segment of the mass media that has emerged, in performing their communicative functions, because they cannot transform and adjust to the rapidly changing society as effectively and quickly as the mobile mass-media structures that were initially formed for the dynamic world can. Since the end of the 20th century, new media conduits, more diverse and complex than in the earlier period of media emergence, have been created to capture the ever-accelerating pace of communication with mass audiences. New media are available on digital devices and involve the active participation of recipients in producing and distributing content.

The digital media generation is to some extent overcoming the one-sided logic of mass-media communications, where one communicator broadcasts to the masses. Postmodernity has brought satellite television, digital media, video and the Internet, email, and social networks, reaching millions of consumers. Thanks to virtual networks, all kinds of media products are globalized, expanded, combined. The media are capturing huge audiences, justifying their original purpose as mass media. These processes contribute to the fact that the media in the postmodern era are evolving from a primary interaction system between the media, society, and mass communications into an integral social institution. Today, mass media is an institutionalized hierarchy of socio-cultural and informational monopolies, which is the fundamental basis for public or private media production [12].

The power and influence of the mass media in influencing society is primarily due to the circumstance of their institutionalization, which originates and develops around their vital activities - the publication and distribution of information. However, despite changing technologies, mass communication is still preserved within the structure of the media as a social institution.

We should also note the reverse process. New communication tools allow imitating fundamental interactions between communicators and communities of people. Social communication between producers of information and consumers often turns into a simulative game that mimics the actual participation of people in various political or social campaigns [13]. The interaction between the subject (person) and the object (transmitted information) of communications involves only an 
illusory representation of public opinion and often biased coverage of social events [14].

Since the mass media are owned or controlled by various socially dominant groups, they occupy vital positions in the spiritual life of society, forming not only the informational but also the axiological space. The editorial policy, the goals of the mass media, and the communicators' views on their mission are subordinated to the tasks of forming a specific model of the world and public consciousness that is beneficial to the dominant or ruling group. Under such conditions, authentic interaction between communicators and society, the objective reflection of events taking place, and the creation of alternative pictures of the world with principles and values of existence that differ from the views of media owners are pretty tricky and sometimes even impossible. That is why the social interaction between the mass media and society has become a specific narrative and linguistic game that imitates the objectivity of this interaction.

\section{CONCLUSION}

In examining the interaction between the media and the individual, it should be noted that modern democratic societies do not have a strictly formalized media institution similar to those that exist in various social spheres (health care, education, justice). The institution of the mass media has specific features that distinguish it from traditional social institutions. Today, the media seek to design and develop their institutional forms and develop their codes and norms. Despite some specific differences in the imperative codes of media structures, they are generally standardized and constitute a media institution whose primary purpose and activity is producing and distributing knowledge (information, ideas, cultural values).

In conclusion, we should note that the institution of mass media today determines human activity and creates forms and models of human behavior. One of these stable patterns of modern human behavior is the constant expectation of information about events and facts in domestic and international life, including the incessant circulation of messages, media shows, and advertisements. Media information daily relieves people of the emptiness of the screen, but, at the same time, it essentially replaces the real social interactions of people. This is both an achievement and a vice of our times.

\section{AUTHORS' CONTRIBUTIONS}

This paper is independently completed by Denis I. Chistyakov, including conceptualization, methodology, investigation, writing original draft preparation, writing review, and editing, resources $-100 \%$.

\section{REFERENCES}

[1] Kravchenko, S.A. Modernity and Postmodernity: Old and New Vision. Sotsiol. Issled. 2007. № 9. P. 24.

[2] Beck, U. Risk Society: Towards a New Modernity. London: Sage, 1992. 272 p.

[3] Virilio, P. The Aesthetics of Disappearance. New York: Semiotext(e), 1991. P. 24.

[4] Zizek, S. Cyberspace or Unbearable Restraint of Existence. Iskusstvo kino. 1998, №1.

[5] McQuail, D. McQuail's Mass Communication Theory. (6th edition). Sage, 2011. P. 4.

[6] Blumer, H. The Mass, the Public, and Public Opinion. Lee A.M. (ed.) New Outlines of the Principles of Sociology. New York: Barnes and Noble, 1939.

[7] Bramson, L. The Political Context of Sociology. Princeton, NJ. Princeton University Press, 1961. 175 p.

[8] Baudrillard J. For a Critique of the Political Economy of the Sign. M., Dobrosvet, KDU, 2007. $336 \mathrm{p}$.

[9] Baudrillard J. Symbolic Exchange and Death. M.: KDU, 2009. 392 p.

[10] Baudrillard J. The Transparency of Evil. M.: Dobrosvet, KDU, 2009. 260 p.

[11] Debray, R. Introduction to Mediology. M.: Praksis, 2009. 368 p

[12] Chistyakov, D. I. Unilateral Exposure to Mass Media: Non-Communicative Person. RUDN Journal of Philosophy. 2020; 24 (3). PP. 467479. DOI: $10.22363 / 2313-2302-2020-24-3-$ 467-479

[13] Bauman, Z. The Individualized Society. M.: Logos, 2005. 390 p.

[14] Chistyakova, O.V. Self and Other in the Communicative Space of the Global World. Proceedings of the 2017 2nd International Conference on Contemporary Education, Social Sciences and Humanities. (ICCESSH 2017). Paris: Atlantis Press, 2017. Pp. 6-11. 